\title{
GnRH antagonist treatment of malignant adrenocortical tumors
}

\author{
Milena Doroszko1,*, Marcin Chrusciel1', Joanna Stelmaszewska², Tomasz Slezak³, Slawomir Anisimowicz4, \\ Ursula Plöckinger5, Marcus Quinkler6,7, Marco Bonomi ${ }^{2}$, Slawomir Wolczynski², Ilpo Huhtaniemi'1,9, Jorma Toppari1,10 \\ and Nafis A Rahman ${ }^{1,2}$
}

1 Institute of Biomedicine, University of Turku, Turku, Finland

2Department of Reproduction and Gynecological Endocrinology, Medical University of Bialystok, Bialystok, Poland

${ }^{3}$ Department of Biochemistry and Molecular Biology, University of Chicago, Chicago, Illinois, USA

${ }^{4}$ Center of Gynecology and Reproductive Endocrinology Artemida, Bialystok, Poland

IInterdisciplinary Center of Metabolism: Endocrinology, Diabetes and Metabolism, Charité University Medicine Berlin, Berlin, Germany

${ }^{6}$ Endocrinology in Charlottenburg, Berlin, Germany

7Department of Clinical Endocrinology, Charité Campus Mitte, Charité University Medicine Berlin, Berlin, Germany

${ }^{8}$ Department of Clinical Sciences \& Community Health, University of Milan, Milan, Italy

9Department of Surgery and Cancer, Faculty of Medicine, Imperial College London, London, U.K.

${ }^{10}$ Department of Pediatrics, Turku University Hospital, Turku, Finland

Correspondence should be addressed to N Rahman: nafis.rahman@utu.fi

*(M Doroszko is now at Department of Immunology, Genetics and Pathology, Section for Neuro-oncology, Uppsala University, Sweden)

\begin{abstract}
Aberrantly expressed G protein-coupled receptors in tumors are considered as potential therapeutic targets. We analyzed the expressions of receptors of gonadotropinreleasing hormone (GNRHR), luteinizing hormone/chorionic gonadotropin (LHCGR) and follicle-stimulating hormone (FSHR) in human adrenocortical carcinomas and assessed their response to $\mathrm{GnRH}$ antagonist therapy. We further studied the effects of the $\mathrm{GnRH}$ antagonist cetrorelix acetate (CTX) on cultured adrenocortical tumor (ACT) cells (mouse $C_{\alpha 1}$ and $Y-1$, and human H295R), and in vivo in transgenic mice (SV40 T-antigen expression under inhibin $\alpha$ promoter) bearing Lhcgr and Gnrhr in ACT. Both models were treated with control (CT), CTX, human chorionic gonadotropin (hCG) or CTX+hCG, and their growth and transcriptional changes were analyzed. In situ hybridization and qPCR analysis of human adrenocortical carcinomas $(n=11-13)$ showed expression of GNRHR in 54/73\%, LHCGR in 77/100\% and FSHR in 0\%, respectively. CTX treatment in vitro decreased cell viability and proliferation, and increased caspase 3/7 activity in all treated cells. In vivo, CTX and CTX+hCG (but not hCG alone) decreased ACT weights and serum $\mathrm{LH}$ and progesterone concentrations. CTX treatment downregulated the tumor markers Lhcgr and Gata4. Upregulated genes included Grb10, Rerg, Nfatc and Gnas, all recently found to be abundantly expressed in healthy adrenal vS ACT. Our data suggest that CTX treatment may improve the therapy of human adrenocortical carcinomas by direct action on GNRHR-positive cancer cells inducing apoptosis and/or reducing gonadotropin release, directing tumor cells towards a healthy adrenal gene expression profile.
\end{abstract}
Key Words
- GNRHR
- LHCGR
- GnRH antagonist
therapy
- cetrorelix

Endocrine-Related Cancer (2019) 26, 103-117 (c) 2019 The authors Published by Bioscientifica Ltd Printed in Great Britain

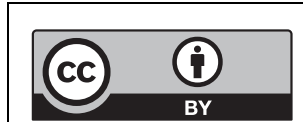

This work is licensed under a Creative Commons Attribution 4.0 International License. 


\section{Introduction}

Adrenocortical adenomas can be detected in around 5\% of the population over the age of 50 (Thompson \& Young Jr 2003), whereas fatal adrenocortical carcinomas are yearly diagnosed in 1-2 patients per million (Allolio \& Fassnacht 2006). Adrenocortical carcinomas have a bimodal distribution, clustering in children under 10 years and adults aged 40-50 years, being 1.5-fold more common in women than men (Allolio \& Fassnacht 2006). Treatment of these cancers mainly involves surgery, adjuvant with mitotane and/or chemotherapy, postoperative radiation and treatment of the hormone excess (Creemers et al. 2016). These forms of therapy remain inefficient, resulting in 5-year survival of only 10-25\% (Allolio \& Fassnacht 2006, Fassnacht \& Allolio 2009).

Ectopic expression of reproductive hormone G-protein coupled receptors (GPCR), such as luteinizing hormone/ chorionic gonadotropin (LHCGR) or gonadotropinreleasing hormone (GNRHR), has been reported in malignancies of reproductive organs (i.e. ovarian, breast or prostate) (Huhtaniemi 2010, Ghanghoria et al. 2016) as well as in adrenocortical disorders, such as adrenocorticortopin-independent adrenal hyperplasia, aldosterone-producing ACA and pregnancy-induced Cushing syndrome (Carlson 2007, Ziegler et al. 2009, Huhtaniemi 2010, Albiger et al. 2011, Plöckinger et al. 2017). Therefore, treatment with GnRH analogues, to block gonadotropin secretion, could provide a therapeutic strategy for the above-mentioned tumors (Limonta et al. 2012, Ghanghoria et al. 2016). GnRH analogues have also been shown to act directly on GNRHR expressing cells and to promote (splenocytes, thymocytes and lymphocytes) or inhibit the growth of normal (ovarian granulosa cells) (Park et al. 2013) and tumorous (prostate, breast, ovary, endometrium, adrenal, lung, pancreatic, melanoma, glioblastoma) cells (Ziegler et al. 2009, Jääskeläinen et al. 2010, Limonta et al. 2012, Park et al. 2013, Seitz et al. 2014). Interestingly, even though the signaling mechanisms of GnRH agonists and antagonists in pituitary cells differ, their direct actions on tumor cells may be similar (Limonta et al. 2012, Ghanghoria et al. 2016). Main effects of GnRH analogue treatment on tumor cells are the inhibition of proliferation, metastatic potential and angiogenesis (Limonta et al. 2012, Ghanghoria et al. 2016). Previous in vitro and in vivo xenograft studies have had important pitfalls. Firstly, these models did not recapitulate the complicated structure of tumor tissue, and, secondly, they lacked the fully functional immune system. Therefore, more accurate assessment of the anti-tumoral efficacy of GnRH analogues in vivo necessitates the inclusion of animals naturally developing tumors and with intact immune system.

Inh $\alpha /$ Tag mice, expressing Simian Virus 40T antigen under the inhibin $\alpha$ promoter, and with an intact immune system, are an example of a mouse model developing tumors (Kananen et al. 1995, 1996, Chrusciel et al. 2014). Intact inh $\alpha /$ Tag mice develop gonadal tumors, but when prepubertally gonadectomized, adrenocortical tumors appear with a hyperplasia-adenoma-adenocarcinoma sequence and abundant LHCGR expression (Kananen et al. 1995, 1996, Rilianawati et al. 1998, Rahman et al. 2001, 2004, Bodek et al. 2005, Vuorenoja et al. 2007, 2008, 2009, Chrusciel et al. 2014, Doroszko et al. 2017a,b). The formation of gonadal and adrenocortical tumors in these mice is gonadotropin dependent, as gonadotropin genetic and pharmacological ablation prevented tumor growth (Rilianawati et al. 1999). Furthermore, elevated LH levels through cross-breeding to LH $\beta$ subunit overexpressing mice (LHßCT mice) (Risma et al. 1995) resulted in simultaneous occurrence of gonadal and adrenocortical tumors (Mikola et al. 2003). Our recent findings on inh $\alpha /$ Tag mice showed that, besides LHCGR, the adrenocortical tumors express Gnrhr (Doroszko et al. 2017a), and SV40Tag expression alone is only able to cause adrenocortical hyperplasia but not adenomas (Doroszko et al. 2017b). The transition from hyperplasia to adenoma required LH/ LHCGR signaling, but thereafter tumor progression became gonadotropin independent (Doroszko et al. 2017b).

Hereby, we revisited the expression of several GPCRs in human adrenocortical carcinomas and mouse adrenal tumors and analyzed further the molecular mechanisms of the GnRH antagonist action on adrenocortical tumor cells in vitro and in vivo.

\section{Materials and methods}

\section{Tissue samples}

Formalin-fixed paraffin blocks from human adrenocortical carcinomas $(n=13)$ were obtained from the archive of the Department of Pathology, Charite Berlin, Germany; the clinical information such as age, sex and ENSAT score information from the Department of Clinical Endocrinology, Charite Berlin, Germany. The study has been approved by the Ethics Committee of the Charite University Hospital, Germany (No. EA1/169/08), and all patients had provided written informed consent. Formalinfixed paraffin-embedded tissues were sectioned $5 \pm 1 \mu \mathrm{m}$ and stored in the darkness at $+4^{\circ} \mathrm{C}$ for future staining. 


\section{Immunohistochemistry}

Localization of proteins was assessed by immunohistochemistry. Antigens were retrieved using 2100 Antigen Retriever (Aptum Biologics Ltd., Southampton, UK) in Tris-EDTA buffer (pH 9, MKI67) or citrate buffer (pH6). Samples were washed in TBS with 0.1\% Tween20 (TBST) (\#P1379, Sigma-Aldrich) and blocked for $1 \mathrm{~h}$ in 3\% BSA in TBST at room temperature (RT). Antibodies against MKI67 (\#MIB-1, Dako, diluted 1:500), GNRHR (\#19950-1-AP, Proteintech, diluted 1:1000), LHCGR (clone 4G2, antibody donated by Dr Marco Bonomi); supernatant diluted 1:8 (Bonomi et al. 2006) or FSHR323 (donated by Dr N. Ghinea) (Vannier et al. 1996) at the concentration of $0.5 \mu \mathrm{g} / \mathrm{mL}$, were applied on the slides and incubated overnight in $4^{\circ} \mathrm{C}$. Endogenous peroxidase activity was quenched by 10 -min incubation in 3\% hydrogen peroxide (Sigma-Aldrich). Depending on the primary antibody host, Dako EnVision+ SystemHRP polymer anti-mouse (K4007, Dako) or anti-rabbit (K4011, Dako) were applied, and visualized with Liquid $\mathrm{DAB}+$ Substrate Chromogen System (Dako). Slides were scanned by Pannoramic 250 Slide Scanner (3DHISTECH Ltd., Budapest, Hungary) and images were taken using Pannoramic Viewer (3DHISTECH Ltd.). The percentage of MKI67-stained cells was assessed using ImmunoRatio web application (http://153.1.200.58:8080/immunoratio/) (Tuominen et al. 2010) from four representative images of each sample.

\section{In situ hybridization}

In situ hybridization (ISH) was performed using RNAscope 2.5 HD Reagent Kit-BROWN (Advanced Cell Diagnostics, Newark, CA, USA) (Wang et al. 2012) with predesigned probes for GNRHR (\#407999), LHCGR (\#300031), FSHR (\#408101), positive control POLR2A (\#310451) and nonsense dapB (from Bacillus S., \#310043). Hybridization was performed according to manufacturer's protocol in HybEZ Oven (Advanced Cell Diagnostics). Slides were scanned by Pannoramic Midi FL slide scanner (3DHISTECH Ltd.) and pictures were taken using Pannoramic Viewer (3DHISTECH Ltd.).

\section{In vitro}

\section{Cell culture}

Co1 (Kananen et al. 1996) cell line was established from a founder female adrenocortical tumor of $\mathrm{C} 57 \mathrm{Bl} / 6$ strain genetic background mouse. Y-1 (ATCC) was derived from a minimally deviated tumor that arose in an adult LAF1 $(\mathrm{C} 57 \mathrm{~L} \times \mathrm{A} / \mathrm{HeJ})$ male mouse, following an exposure of the mouse to the radiation of an atomic blast (Cohen et al. 1957). Human H295R (ATCC) cell line was isolated from a female adrenocortical carcinoma patient (Rainey et al. 1994). These cell lines used in our study were mycoplasmafree. DMEM/F12 (\#D2906, Sigma-Aldrich) culture media containing $5 \mathrm{U} / \mathrm{mL}$ of penicilin/streptomycin (\#15140-122, Fisher Scientific) were supplemented for each cell line as follows, C $\alpha 1$ 10\% fetal bovine serum (FBS); Y-1 15\% fetal horse serum (FHS) and 2.5\% FCS; H295R 2.5\% NuSerum (\#355100, Corning, New York, NY, USA) and 1× Corning ITS Premix Universal Culture Supplement (\#354352, Corning).

Cetrorelix acetate (\#C5249, Sigma-Aldrich) was dissolved in $0.1 \%$ DMSO (\#D8418, Sigma-Aldrich). Recombinant hCG was kindly donated by Organon (Oss, Netherlands). Concentrations of cetrorelix acetate and hCG were validated and set for $10 \mu \mathrm{M}$ and 10ng/mL respectively. For all experiments, Y-1 and H295R cells were seeded and stimulated in full culture media, whereas C $\alpha 1$ cells in medium containing $2.5 \%$ FBS. After attaching overnight medium was changed to the medium containing $0.1 \%$ DMSO as control (CT), $10 \mu \mathrm{M}$ CTX (CTX), $10 \mu \mathrm{M}$ CTX and $10 \mathrm{ng} / \mathrm{mL}$ of hCG (CTX + hCG) or $10 \mathrm{ng} / \mathrm{mL}$ of hCG (hCG) solutions.

\section{Viability test}

Viability of the cells was checked using MTS CellTiter 96 Aqueous Non-Radioactive Cell Proliferation Assay (Promega). In brief, cells were seeded on 24-well plates $(\mathrm{C} \alpha 1=120,000$ cells/well, Y- $1=180,000$ cells/well, H295R = 180,000 cells/well) and after $48 \mathrm{~h}$ of treatment medium was changed for DMEM/F12 medium containing MTS reagent. Cells were incubated for $240 \mathrm{~min}$ in $37^{\circ} \mathrm{C}$ and absorbance at $495 \mathrm{~nm}$ was read using Wallac 1420 Victor 2 Microplate Reader (Perkin Elmer).

\section{Proliferation test}

Cells were seeded on 96-well plate $(\mathrm{C} \alpha 1=4000$ cells/well, Y-1 $=8000$ cells/well, H295R $=8000$ cells/well) and after $48 \mathrm{~h}$ of treatment medium was decanted and platesfrozenin $-80^{\circ}$ Covernight. Afterthawing, CyQUANT Cell Proliferation Assay Kit (\#C7026, Life Technologies) was applied and DNA standard curves for each cell line were prepared according to manufacturer's instructions. Fluorescence was read at $\mathrm{Ex} / \mathrm{Em}=480 \mathrm{~nm} / 520 \mathrm{~nm}$ with Wallac 1420 Victor2 Microplate Reader (Perkin Elmer). Results were recalculated using determination based

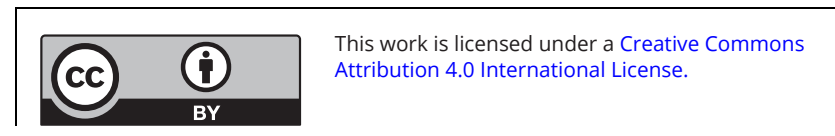




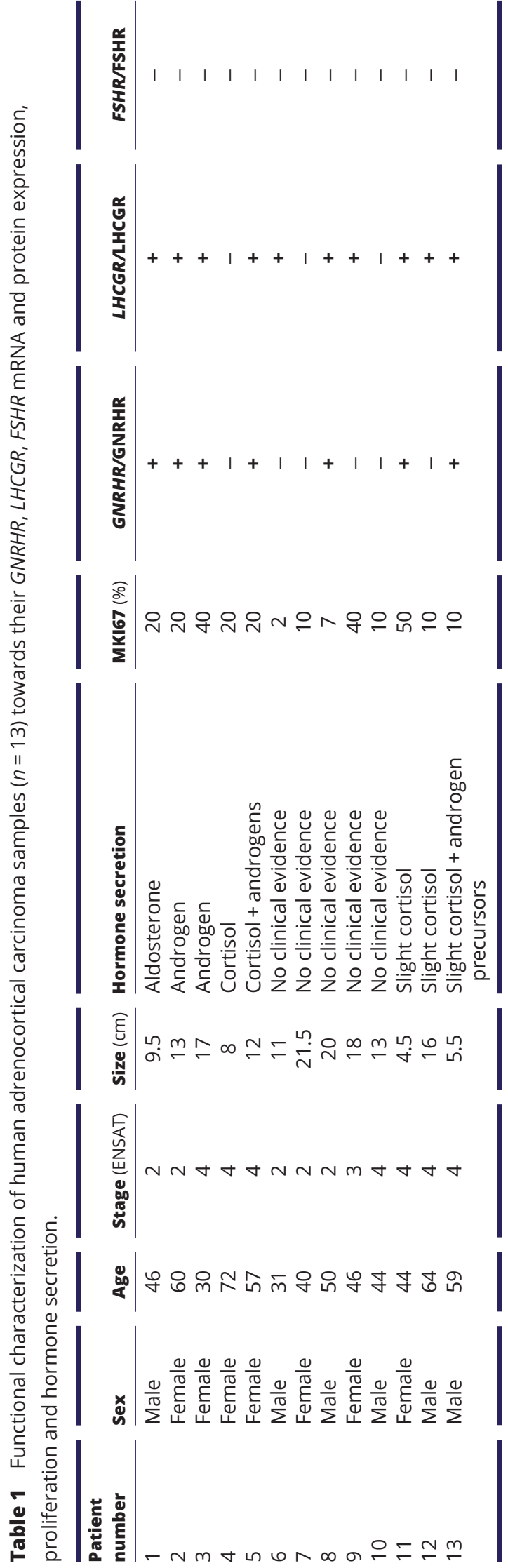

https://erc.bioscientifica.com https://doi.org/10.1530/ERC-17-0399
(C) 2019 The authors Published by Bioscientifica Ltd. Printed in Great Britain on a DNA standard curve, normalized to the control group for every cell line and presented as a percent of stimulation.

\section{Apoptosis assay}

Activity of Caspase 3/7 was assessed using Caspase Glo 3/7 kit (Promega) according to the provided protocol. In brief, cells were seeded 8000/well on a 96-well plate, attached overnight and treated with CT (0.1\% DMSO as control) or $10 \mu \mathrm{M}$ CTX (CTX) for $6 \mathrm{~h}$. Absolute luminescence was normalized by CT-treated values.

\section{GNRHR knockdown studies}

To knockdown GNRHR in H295R cells, we delivered anti-GNRHR ON-TARGETplus SMARTpool (\#L-00551700-0005, Dharmacon) libraries using Lipofectamine RNAiMAX Transfection Reagent (Fisher Scientific). As a negative and positive control ON-TARGETplus Non-targeting Pool (\#D-001810-10-05) and AllStars Hs Cell Death Control siRNA (\#SI04381048, Qiagen) were used, respectively. Reverse transfection according to manufacturer's protocol, in triplicates with a final 50 pmol siRNA concentration was performed and after overnight incubation medium was changed into full culture medium. After $72 \mathrm{~h}$, each of the cell replicates were detached and seeded either onto 96-well plates for proliferation ( $n=6 /$ replicate) and caspase $3 / 7$ activity studies ( $n=3 /$ replicate) or harvested for Western blot analysis ( $n=1 /$ replicate).

\section{Western blot}

Cells were rinsed with cold PBS and scraped on ice with RIPA buffer (Fisher Scientific) with addition of protease and phosphatase inhibitors (cOmplete ULTRA Tablets and PhosSTOP Phosphatase Inhibitor Cocktail Tablets, Roche). Equal amounts of total protein $(20 \mu \mathrm{g})$ were separated on $10 \%$ polyacrylamide gels for $1.5 \mathrm{~h}$ at $100 \mathrm{~V}$ in $4^{\circ} \mathrm{C}$. Proteins were transferred onto PVDF membranes using a semi-dry transfer for $30 \mathrm{~min}$ at $20 \mathrm{~V}$. Membranes were blocked in 5\% non-fat milk and incubated overnight with anti-GNRHR primary antibody (1:500; GNRHR03, MA5-11538, Invitrogen) at $4^{\circ} \mathrm{C}$. Next day, membranes were washed in TBST and anti-mouse HRP-linked secondary antibody (Abcam) was applied for $30 \mathrm{~min}$ at RT. Amersham Biosciences ECL detection system (GE Healthcare, Little Chalfont, UK) was used for signal visualization. Images were taken using ChemiDoc MP imager (Bio-Rad). After visualization membranes were stripped using ReBlot

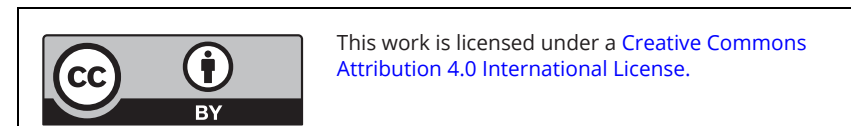


A
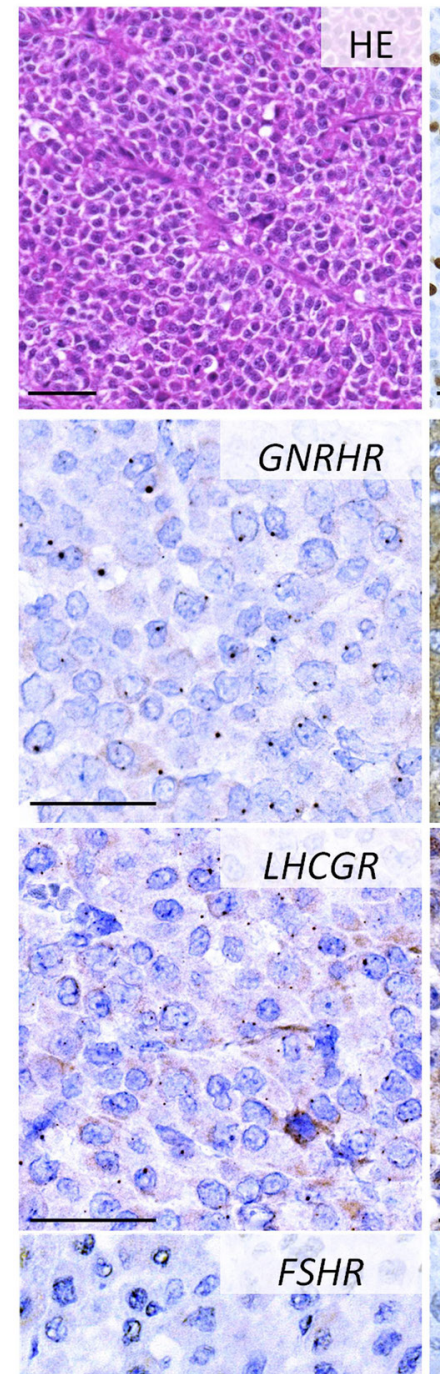

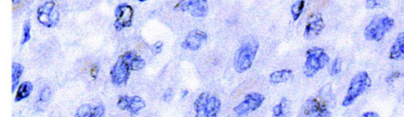

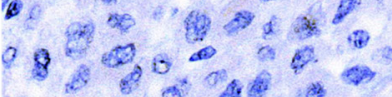

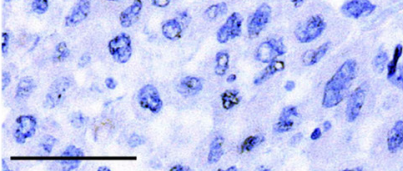

ACC
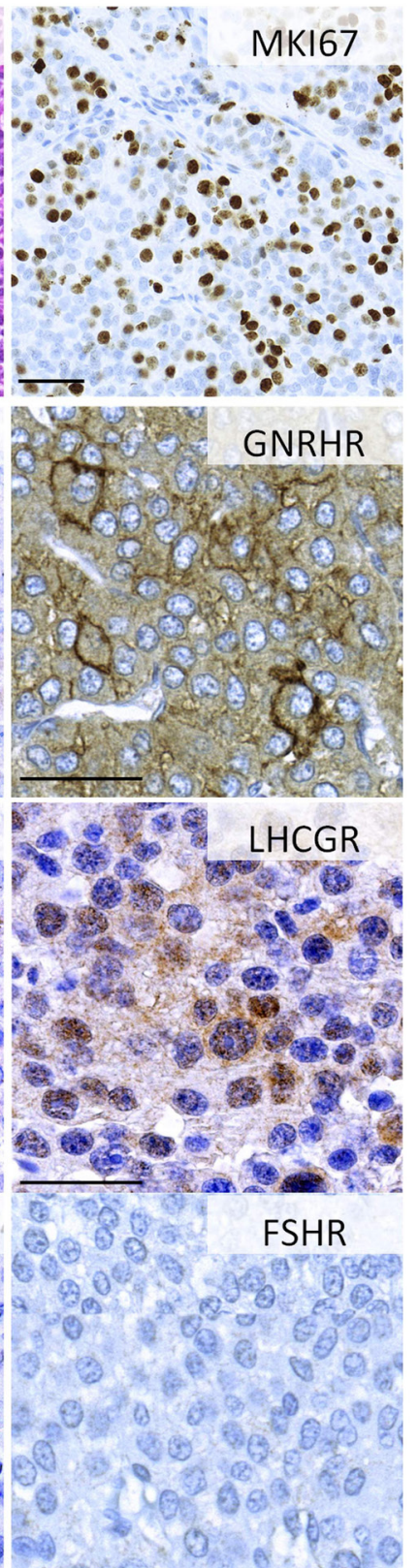

B Inha/Tag
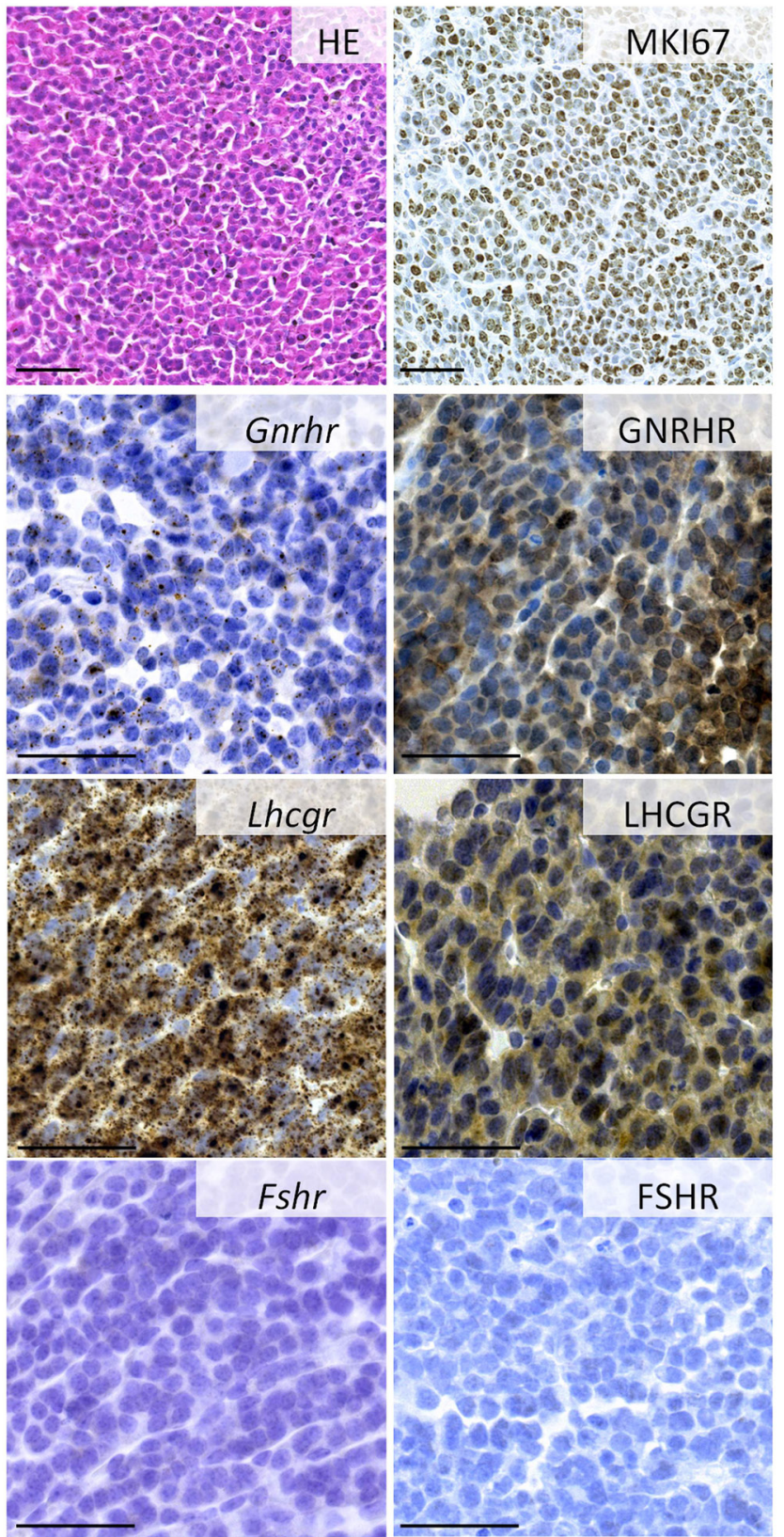

FSHR

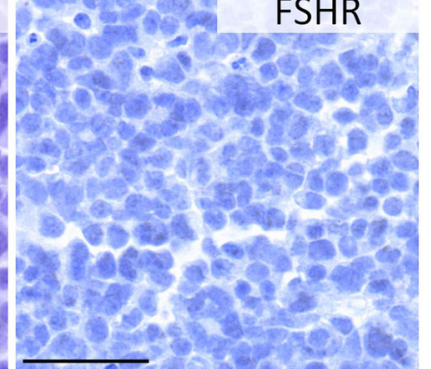

Figure 1

Localization of gonadotropin receptors in human and mouse adrenocortical tumors/cancer. Representative images of hematoxylin and eosin, immunolocalization of MKI67, in situ RNA/protein localization of GNRHR, LHCGR and FSHR in human adrenocortical carcinoma sections from Patient 11 (panel A) or adrenocortical tumor sections of inh $\alpha /$ Tag mouse (panel B). Bar $=50 \mu \mathrm{m}$.

Plus Strong Antibody Stripping Solution (SigmaAldrich), blocked in 5\% non-fat dry milk and incubated overnight $\left(4^{\circ} \mathrm{C}\right.$ with gentle agitation) with primary anti-actin beta (ACTB) antibody (1:1000; A2228, SigmaAldrich). Intensity of the signals was calculated using Image $(\mathrm{NIH})$ software based on the measurements of three membranes. Printed in Great Britain

\section{In vivo}

In this study, we used inh $\alpha /$ Tag (transgenic mice expressing SV40 Tag oncogene under the inhibin a promoter) (Kananen et al. 1995, 1996) males and females ( $n=6-8 /$ gender/group). To induce adrenocortical tumors, animals were prepubertally (in between 21 and 24 days of

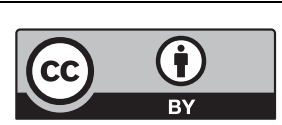


their lives) gonadectomized under Isoflurane anesthesia (Isoflo, Orion, Finland). Temgesic (buprenorphine, $0.1 \mathrm{mg} / \mathrm{kg} / 8 \mathrm{~h}$ ) (Schering-Plough, Brussels, Belgium) and Comforion (ketoprofen, $5 \mathrm{mg} / \mathrm{kg} / 24 \mathrm{~h}$ ) were administered subcutaneously as a post-operative analgesia. Mice were raised in a pathogen-free media surrounded with controlled light (12 h light: $12 \mathrm{~h}$ darkness) and temperature $\left(21 \pm 1^{\circ} \mathrm{C}\right)$. Mice were housed two to five per cage, fed with mouse chow SDS RM-3 (Whitham, Essex, UK) and tap water ad libitum. Ethics Committees for animal experimentation of the Turku University and the State Provincial Office of Southern Finland approved all the animal experiments (ESAVI/3324/04.10.07/2014).

\section{Preparation of drugs and treatments}

Cetrorelix acetate (CTX, Sigma-Aldrich) was dissolved in sterile water and $0.75 \mathrm{mg} / \mathrm{mL}$ stock solution, kept in $+4^{\circ} \mathrm{C}$ and used out within 6 days after reconstitution. Pregnyl $5000 \mathrm{IU}$ (Merck) was dissolved in $99 \mathrm{~mL}$ of Natriumchlorid B. Braun $9 \mathrm{mg} / \mathrm{mL}$ (\#630966, Braun, Melsungen,
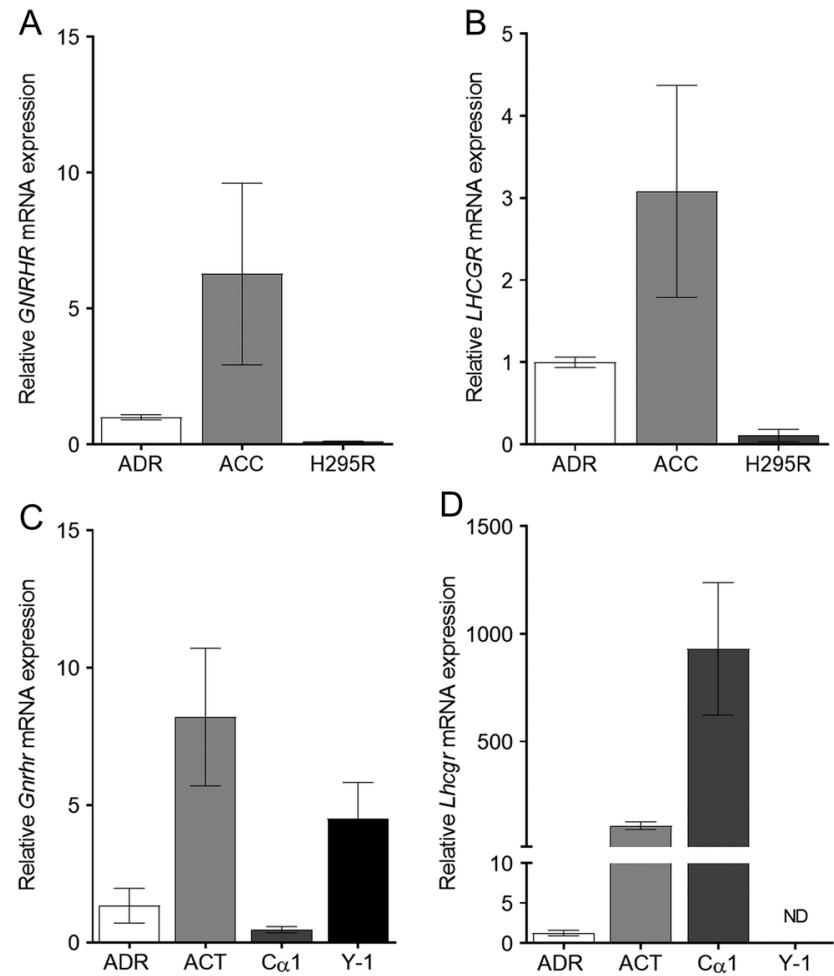

Figure 2

mRNA levels of GNRHR/Gnrhr and LHCGR/Lhcgr in normal and adrenal tumor/cancer tissues and cell lines. Expression of GNRHR (A) and LHCGR (B) in normal human adrenals (ADR) $(n=3)$, adrenocortical carcinomas (ACC) $(n=11)$ and H295R cell line ( $n=3)$. Expression of Gnrhr (C) and Lhcgr (D) in normal mouse ADR $(n=5), \operatorname{ACT}(n=5)$ and cell lines $\mathrm{C} \alpha 1$ and Y-1. ACC, adrenocortical cancer, ACT, adrenocortical tumor; ADR, normal adrenal.
Germany), aliquoted into $1 \mathrm{~mL}$ syringes and frozen in $-20^{\circ} \mathrm{C}$. Single dose of cetrorelix acetate was $3 \mathrm{mg} / \mathrm{kg} / 48 \mathrm{~h}$, whereas Pregnyl $5 \mathrm{IU} / 30 \mathrm{~g} /$ week. At the age of 6.5 months, GDX inh $\alpha /$ Tag mice were randomly divided into experimental groups ( $n=6-8 /$ group/gender) and injected intraperitoneally for 21 days with weight-dependent amount of substance (1): saline as control (CT; Natrium chloride B. Braun $9 \mathrm{mg} / \mathrm{mL}$ (Braun)) (2), CTX (3), CTX together with Pregnyl (CTX+hCG) or (4) Pregnyl only (hCG). On day 23, mice were killed by exsanguination under isoflurane anesthesia. Blood was collected into a tube consisting $0.5 \mathrm{M}$ sterile EDTA solution, and plasma was separated by centrifugation at $1800 \boldsymbol{g}$ for $10 \mathrm{~min}$ in $4^{\circ} \mathrm{C}$, and stored in $-80^{\circ} \mathrm{C}$ for hormone measurements. After taking the weights, tissues were snap-frozen in liquid nitrogen or fixed with $4 \%$ paraformaldehyde.

\section{RNA isolation and gene expression analysis}

Total RNA from mouse adrenal tumors ( $n=5$ /group/sex), 3 passages of cell lines (C $\alpha 1, \mathrm{Y}-1, \mathrm{H} 295 \mathrm{R}), 11$ adrenocortical carcinomas, 2 healthy adrenal glands or C $\alpha 1$ and Y-1 cells treated for $24 \mathrm{~h}$ with control (CT; $0.1 \%$ DMSO as control) and CTX was extracted using TRIsure reagent (Bioline Reagents Ltd., London, UK) according to manufacturer's protocol. RNA was quantified with Nanodrop (Fisher Scientific) and qualified by gel electrophoresis. Nine hundred nanograms of total RNA were treated with Amplification Grade DNase I (\#AMPD1-1KT, SigmaAldrich) and transcribed $\left(1 \mathrm{~h}\right.$ in $\left.48^{\circ} \mathrm{C}\right)$ using SensiFAST cDNA Synthesis Kit (\#BIO-65053, Bioline Reagents Ltd.). qPCR reaction was consisting Fast SYBR Green Master Mix (Fisher Scientific), $7.5 \mathrm{ng}$ of DNA template and primers from Supplementary Table 1(see section on supplementary data given at the end of this article). qPCR was run on CFX Real Time PCR Detection System (Bio-Rad) in total reaction volume of $10 \mu \mathrm{L}$ in duplicates. Cycling conditions were as follows: $95^{\circ} \mathrm{C}$ for $30 \mathrm{~s},\left(95^{\circ} \mathrm{C}\right.$ for $10 \mathrm{~s}, 60-62^{\circ} \mathrm{C}$ for $\left.30 \mathrm{~s}\right) \times 40,72^{\circ} \mathrm{C}$ for $2 \mathrm{~min}, 65-95^{\circ} \mathrm{C}$ melt curve. Reference genes were validated for specific tumor type and cell line using Bio-Rad CFX Manager Software (Bio-Rad). Gene expression was normalized by at least 2 reference genes using qBase MSExcel VBA applet (Hellemans et al. 2007).

\section{In silico}

To study global gene expression changes affected by CTX treatment, we compared adrenals of GDX inh $\alpha /$ Tag mice after 21-day treatment with CTX or CT ( $n=4 /$ group). 

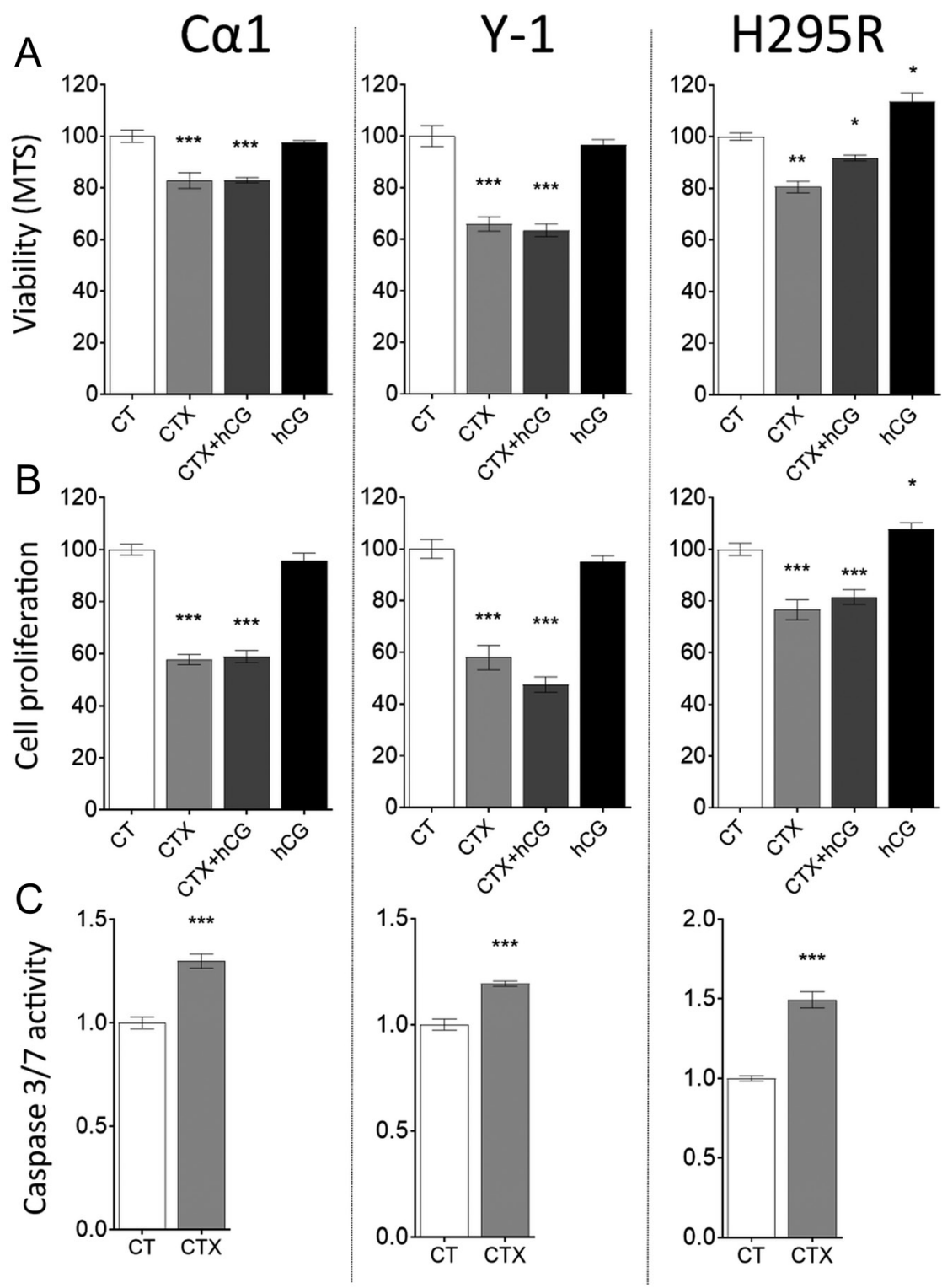

\section{Figure 3}

Cell viability, proliferation and caspase $3 / 7$ activity in vitro. Viability (A) and proliferation (B) of $C_{\alpha} 1$, $\mathrm{Y}-1$ and H295R cells after $48 \mathrm{~h}$ treatment with $\mathrm{CT}$, CTX, CTX and hCG or hCG alone. Caspase 3/7 activity (C) in $\mathrm{C} \alpha 1, \mathrm{Y}-1$ and $\mathrm{H} 295 \mathrm{R}$ cells assessed after culture with CTX for $6 \mathrm{~h}$ (mean \pm S.E.M.; ${ }^{*} P \leq 0.05$. ${ }^{*} P \leq 0.01$. $\left.* * * P \leq 0.001\right) . \mathrm{CT}, 0.1 \%$ DMSO as control; CTX, cetrorelix acetate; hCG, human chorionic gonadotropin.

Total RNA was extracted using RNeasy Mini Kit(Qiagen) according to manufacturer's protocol and qualified using Bioanalyzer nano kit (Agilent Technologies). cDNA was synthetized using the MessageAmp II aRNA Amplification Kit (Applied Biosystems) and ran on Agilent whole mouse genome oligo microarrays 4X44K (\#GPL7202, Agilent Technologies, Santa Clara, CA, USA) accordingly to manufacturer's protocol. Quantile normalization with Iimma R/Bioconductor package and a row-wise t-test were performed. Genes with fold-change higher than 2 and $P$-value lower than 0.05 were considered significant. Targets with $P$-value $<0.1$ and fold-change $<1.2$ for males and females were compared in Venn diagram (http:// bioinfogp.cnb.csic.es/tools/venny/). List of treatment affected targets was uploaded to the PANTHER classification system (Mi et al. 2013) and statistical overrepresentation test was performed. Genes were classified using PANTHER GO-Slim Biological Processes and PANTHER pathways annotation data sets.

\section{Statistical analysis}

To detect statistical differences between two or more experimental groups, we used Mann-Whitney $U$ test or Kruskal-Wallis test with multiple comparison of mean range as post hoc analysis respectively. Numerical data were presented as mean \pm s.E.M. Statistical analysis and graphs were prepared using Graph Pad Prism 6 (GraphPad Software), and $P<0.05$ values were considered as significant. 


\section{Results}

\section{Expression of GNRHR, LHCGR and FSHR in} adrenocortical tumors and cell lines

We determined the mRNA and protein expression of GNRHR, LHCGR and FSHR genes in samples from 13 patients, 6 males and 7 female patients, 30-72 years of age, presenting with diverse hormone excess manifestations (Table 1). Adrenocortical carcinoma samples were classified according to the European Network for the Study of Adrenal Tumors (ENSAT) scale from 2 to 4 , and MKI67 proliferation index spanning between 2 and 50\% (Table 1). In order to assess whether the adrenocortical carcinoma samples express GNRHR, LHCGR and FSH expression was studied using a commercial in situ hybridization RNAscope kit with single transcript resolution (Wang et al. 2012). We detected GNRHR in 54\%, LHCGR in 77\% and FSHR in $0 \%$ of the cancer samples (Table 1 ). The representative images of hematoxylin and eosin, immunohistochemical staining of MKI67, and localization of GNRHR/GNRHR, LHCGR/LHCGR and FSHR/FSHR transcripts and proteins in the human adrenocortical malignancies and in inho/Tag adrenals are presented in the left (Fig. 1A) and right (Fig. 1B) panel, respectively. qPCR confirmed the expression of GNRHR/Gnrhr (Fig. 2A and C) and LHCGR/Lhcgr (Fig. 2B and D) in the normal human and mouse adrenals, adrenocortical tumors and H295R, C $\alpha 1$, Y-1 cell lines (except Lhcgr in Y-1).

\section{CTX decreased cell viability and proliferation in vitro and tumor size in vivo}

To evaluate the potential tumor-regressing effect of CTX, we treated adrenocortical tumor cells in vitro and in vivo. To discriminate between direct and indirect CTX effects, we maintained LHCGR stimulation with hCG treatment. CTX alone or in combination with hCG (CTX+hCG) decreased the viability (Fig. 3A) and proliferation (Fig. 3B) of C $\alpha 1$, Y-1 and H295R cells, whereas hCG alone significantly increased the viability and proliferation of H295R cells only (Fig. 3A and B). Moreover, CTX treatment increased the activity of caspase $3 / 7$ in all treated cell lines (Fig. 3C). In vivo CTX and CTX + hCG treatments decreased adrenocortical tumor size of male (Fig. 4A) and female (Fig. 4B) mice as well as decreased LH (Fig. 4C and D) and progesterone (Fig. 4E and F) plasma concentrations when compared to CT. hCG treatment alone had no impact on the tumor size or plasma hormone concentrations (Fig. 4C, D, E and F).
Males
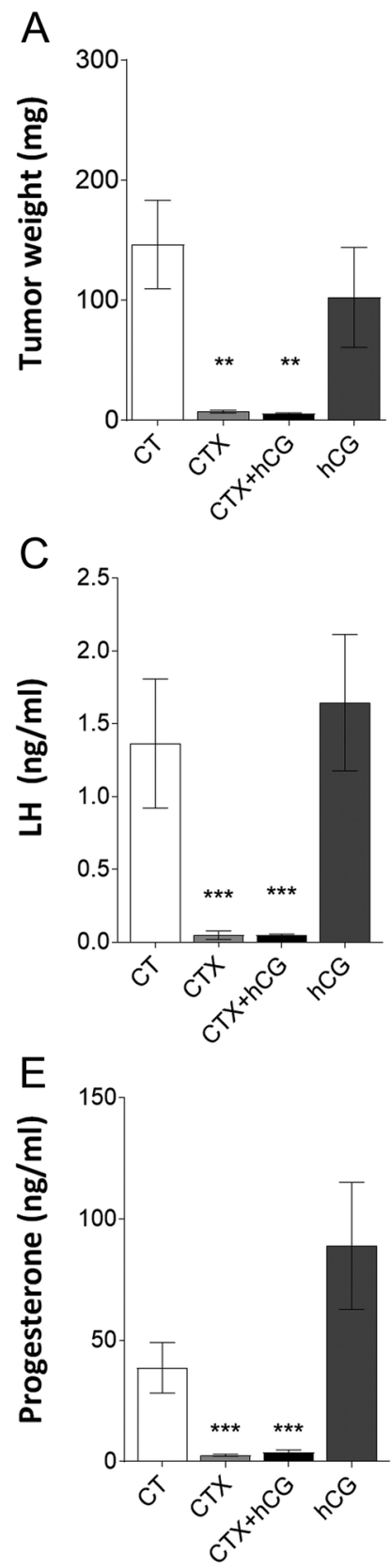

$\mathrm{F}$

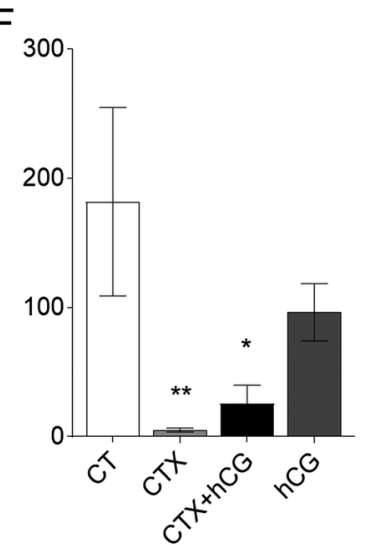

Figure 4

CTX treatment efficacy in vivo. Adrenal tumor weights ( $A$ and $B$ ) and plasma LH (C and D) and progesterone ( $E$ and $F$ ) concentrations of mice treated for 21 days with saline as control (CT), CTX, CTX and hCG, or hCG. ( $n=6$-8/group; mean \pm S.E.M.; $\left.{ }^{*} P \leq 0.05 . * * P \leq 0.01 . * \star * P \leq 0.001\right) . C T$, saline; CTX, cetrorelix acetate; hCG, human chorionic gonadotropin.

\section{CTX acts through GNRHR expressed in tumor cells}

To confirm that the effect of CTX on adrenocortical carcinoma cells acts through GNRHR, we performed siRNA-mediated GNRHR knockdown in human H295R cells. Western blot analysis (Fig. 5A) revealed 78\%

This work is licensed under a Creative Commons Attribution 4.0 International License. 
A
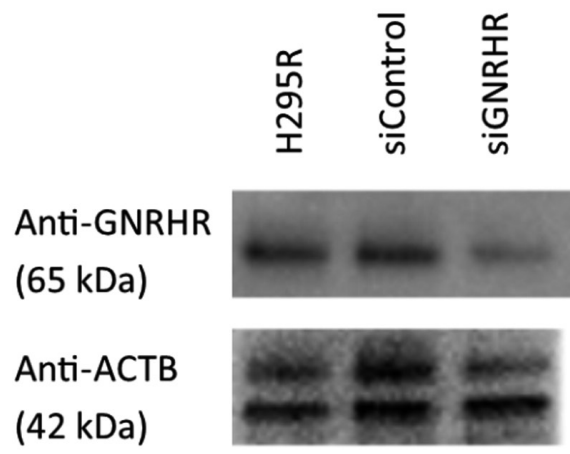

B

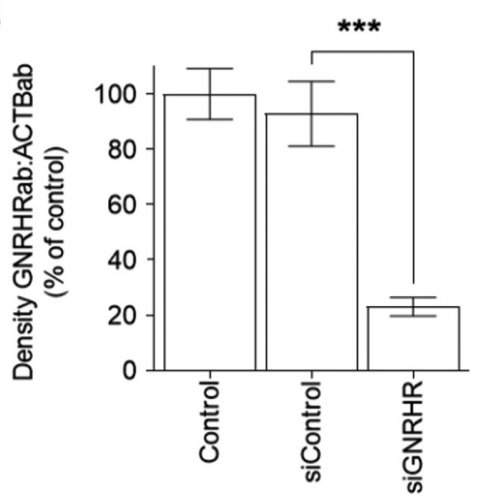

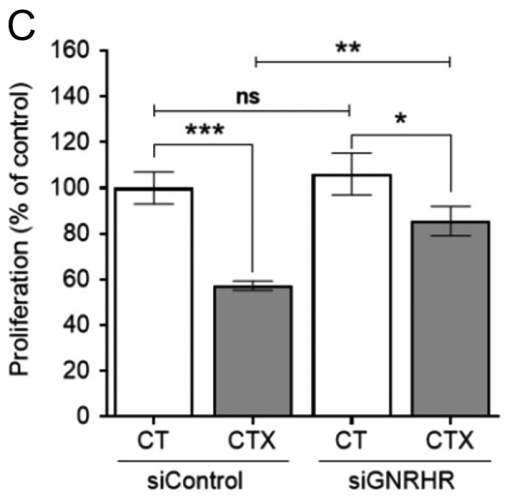

D

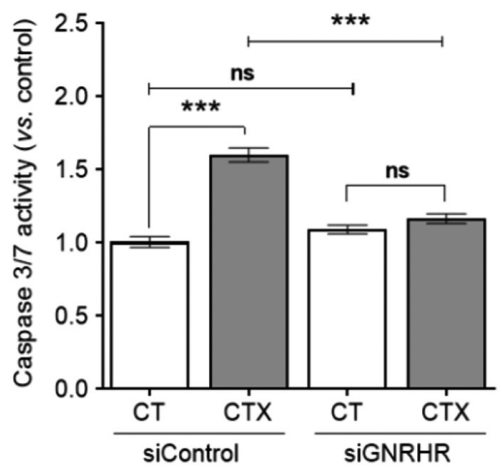

Figure 5

GNRHR knockdown in H295R adrenocortical carcinoma cells. Western blot analysis of GNRHR expression in WT (H295R), transfected with non-targeting (siControl) or GNRHR-targeting (siGNRHR) siRNA H295R adrenocortical carcinoma cells (A). Densitometric analysis of the GNRHR protein levels in H295R, siControl and siGNRHR cells $(n=3)(B)$. The effect of CTX treatment on proliferation $(n=12)$ (C) and caspase 3/7 activation $(n=9)$ (D) in siControl and siGNRHR cells (mean \pm S.E.M.; $* P \leq 0.05 .{ }^{*} P \leq \leq 0.01$. $\star \star \star P \leq 0.001)$. knockdown of GNRHR protein levels (siGNRHR), as compared to cells transfected with non-targeting siRNA libraries (siControl) (Fig. 5B). Basal proliferation between siGNRHR and siControl cells was similar, and after 48-h CTX treatment, the proliferation of both was decreased (Fig. 5C). However, the inhibition of siGNRHR cell proliferation was significantly greater than that of siControl cells (Fig. 5C). Caspase 3/7 activity was similar in siGNRHR and siControl, but after CTX treatment significantly increased only in siControl cells (Fig. 5D).

\section{Global gene expression changes of adrenocortical tumors in inh $\alpha /$ Tag mice}

cDNA microarray analyses were run to identify the potential biological processes and pathways affected by CTX in ACTs of inh $\alpha /$ Tag mice. Due to high individual variation of tumor sizes, we considered fold change of \pm 1.2 and $P$ value $<0.1$ significant. Complete cDNA microarray data can be found through ArrayExpress (accession number E-MTAB-5310). In females, CT vs CTX, 1714 genes were differently expressed, 918 upregulated and 796 downregulated. In males, CT vs CTX, 4390 genes were altered, 2506 up- and 1884 downregulated (Fig. 6A). As the individual variation of tumor size was lower in males than in females, we used the male dataset for further processing. Enrichment analysis with PANTHER classification system was used to cluster genes into biological processes and pathways. The most interesting processes (marked with arrowheads) were growth, biological adhesion, immune system, development and response to stimulus (Fig. 6B). Among dysregulated pathways, the most conspicuous (marked with arrowheads) were p53, apoptosis signaling, EGF receptor signaling, FGF signaling, gonadotropin-releasing hormone receptor, G-protein signaling pathways, angiogenesis, inflammation mediated by chemokine and cytokine signaling and Wnt signaling pathways.

\section{Gene expression signatures of CTX treatment in adrenocortical tumors of inh $\alpha /$ Tag mice}

Previously, we reported an array of genes up- or downregulated in adrenocortical tumors of inh $\alpha /$ Tag mice, when compared to WT littermates (Doroszko et al. 2017a). Interestingly, a subset of the genes such as transcription factor GATA4 (Gata4), Lhcgr, sarcoglycan delta ( $S g c d)$, 
A
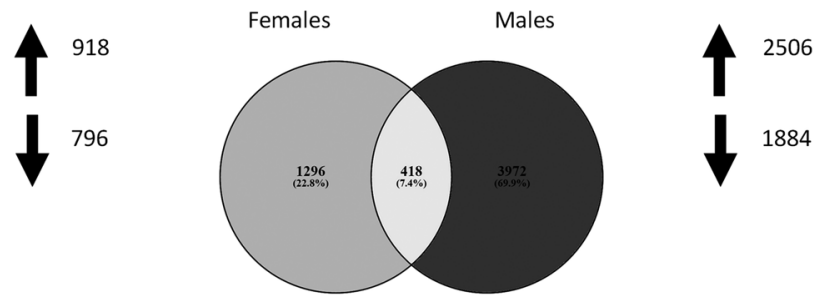

B

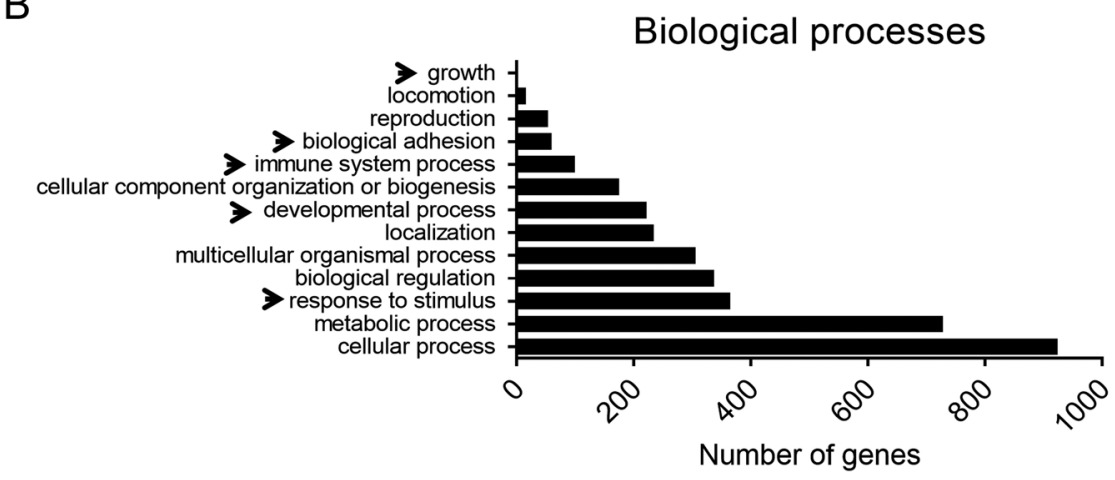

C

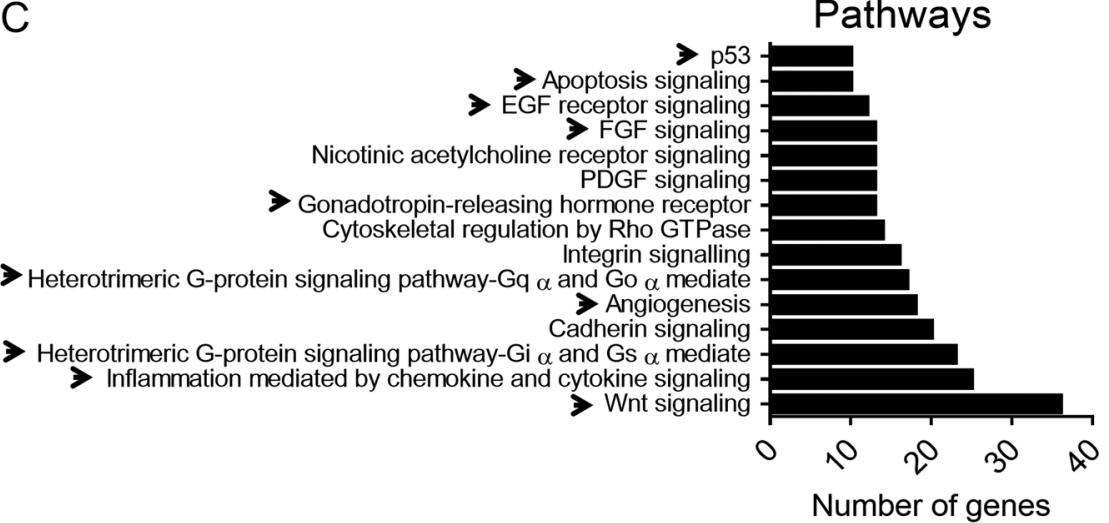

Figure 6

Gene ontology (GO) classification based on biological processes and pathways affected by CTX treatment in vivo. Venn diagram of upregulated and downregulated genes in the adrenal glands of male and female mice treated with CTX (cetrorelix acetate) or CT (saline as control) for 21 days (A). Significantly upregulated or downregulated genes were classified based on the biological processes (B) and pathways (C) they are involved in. The analysis shows the number of dysregulated genes in the adrenocortical tumors of inh $\alpha / T a g$ treated with CT vS CTX. matrix metallopeptidase 24 (Mmp24), growth factor receptor-bound protein 10 (Grb10), RAS-like estrogenregulated growth inhibitor (Rerg), gonadotropin-releasing hormone receptor (Gnrhr), G-protein-coupled receptor nuclear factor of activated $\mathrm{T}$ cells, calcineurin-dependent 2 (Nfatc2) and guanine nucleotide-binding protein alphastimulating complex locus (Gnas) also appeared in this microarray analysis. qPCR validation of the microarray analysis in murine adrenocortical tumors treated with CTX vs CT showed downregulation of Gata4 (Fig. 7A), Lhcgr (Fig. 7B), Cyclin A1 (Ccna1) (Fig. 7C) and upregulation of extracellular matrix compounds such as $S g c d$ (Fig. 7D), Mmp24 (Fig. 7E); genes related to cell growth suppression, Grb10 (Fig. 7F), Rerg (Fig. 7G); G0/G1 Switch 2 (G0s2) (Fig. 7H); Tumor Suppressor Candidate 5 (Tusc5) (Fig. 7I) or GPCR-mediated Ras protein-specific guanine nucleotidereleasing factor 1 (Rasgrf2) (Fig. 7J). In addition, we found upregulation of Gnrhr (Fig. 7K) and the downstream mediators of G-protein-coupled receptor Nfatc2 (Fig. 7L) and Gnas (Fig. 7M). Interestingly, none of these genes were altered in CTX-treated cells in vitro (Fig. 7A, B, C, D, E, F, G, $\mathrm{H}, \mathrm{I}, \mathrm{J}, \mathrm{K}, \mathrm{L}$ and $\mathrm{M}$ ).

\section{Discussion}

In recent years, several studies have detected the expression and function of the two reproductive hormone receptors, GNRHR and LHCGR, in non-gonadal tissues and malignancies (Alevizaki et al. 2006, Bernichtein et al. 2008, Lacroix et al. 2010, Banerjee \& Fazleabas 2011, Limonta et al. 2012). In adrenal glands, gonadotropins, especially LH, may exert hormonal and hyperplastic effect (Carlson 2007, Plöckinger et al. 2017) as well as induce various adrenocortical pathologies. GNRHR expression has also been found in adrenocortical adenomas producing aldosterone (Albiger et al. 2011). Previously,

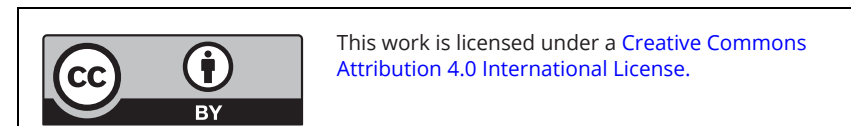



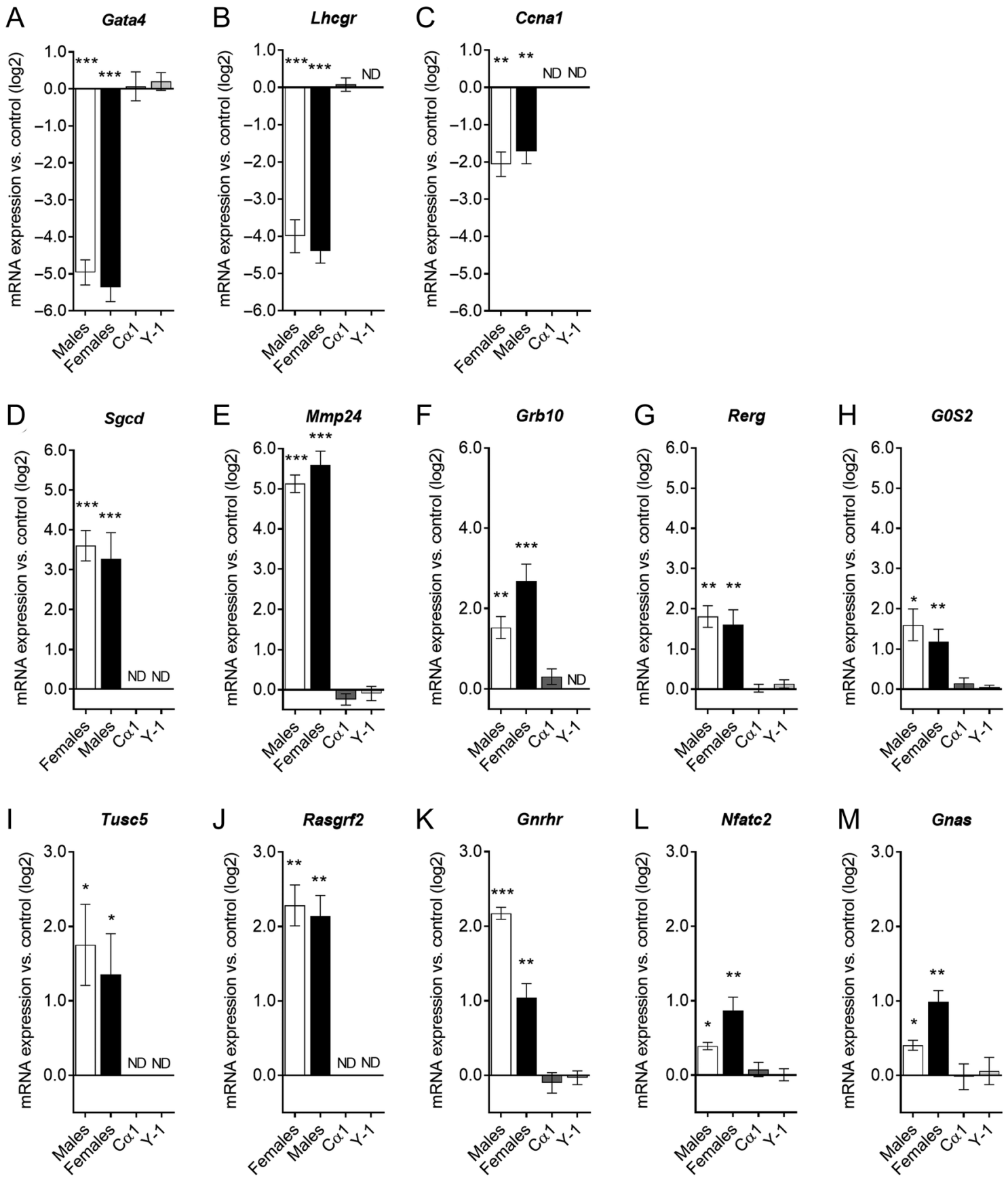

Figure 7

qPCR validation of selected genes from microarray study in inh $\alpha / T a g$ adrenal tumors and cell lines (C $\alpha 1$ and $Y-1)$ treated with CTX vs CT. Gene expression of Gata4 (A), Lhcgr (B), Ccna1 (C), Sgcd (D), Mmp24 (E), Grb10 (F), Rerg (G), G0s2 (H), Tusc5 (I), Rasgrf1 ()), Gnrhr (K), Nfatc2 (L), Gnas (M) in inho/Tag adrenal tumors and $\mathrm{C} \alpha 1$ and $\mathrm{Y}-1$ cell lines treated with CTX (cetrorelix acetate) vs CT (0.1\% DMSO as control). ( $n=3-5 /$ group; mean \pm S.E.M.; $* P \leq 0.05$. $* \star P \leq 0.01$. $\star \star \star P \leq 0.001)$

GNRHR localization was shown in normal adrenal glands (medulla and cortex), adrenocortical adenomas and in the SW13 adrenocortical cell line, but never in adrenocortical carcinomas (Ziegler et al. 2009). LHCGR expression has been demonstrated in normal human adrenals (Pabon et al. 1996) and in various adrenocortical malignancies (Carlson 2007). FSHR has been found only by immunohistochemical localization in the intra- and peri-tumoral vessels of adrenal tumors (Pawlikowski et al. 2012). Reliable localization of gonadotropin receptors is challenging due to a lack of good-quality commercially available antibodies. Therefore, in our studies, we analyzed 
their expression levels by qPCR, mRNA localization in the tissue sections by a commercial in situ hybridization RNAscope kit and protein localization using in-house antibodies. We found that human adrenocortical carcinomas and mouse adrenocortical tumors expressed GNRHR and LHCGR mRNA and protein at variable levels, probably due to the well-known high heterogeneity of the tumors (Allolio \& Fassnacht 2006). However, we were unable to detect FSHR transcripts or protein, in contrast to an earlier report (Pawlikowski et al. 2012), which used only immunohistochemistry. The inconsistency between RNA levels and protein detection using poorly characterized antibodies against FSHR is well recognized, necessitating RNA and protein measurements in tandem to ensure specificity and sensitivity of the FSHR detection (Stelmaszewska et al. 2016).

The present in vivo and in vitro data unequivocally showed that CTX could act directly on tumors causing their regression. CTX treatment decreased cell viability and proliferation as well as increased apoptosis in mouse and human adrenocortical tumors and cancer cell lines. GNRHR knockdown to reduce CTX action ultimately confirmed the on-target CTX effect. Similar direct GnRH antagonist effects on proliferation and cell death have been reported in prostate (Sakai et al. 2015), breast, uterine, lung (Ghanghoria et al. 2016) and adrenocortical (Ziegler et al. 2009) cell lines. Previous CTX treatment of adrenocortical tumors in inh $\alpha /$ Tag mice (Vuorenoja et al. 2009) showed tumor regression, which was attributed to systemic effect through inhibition of LH release. In contrast, we found now that hCG treatment did not affect $\mathrm{C} \alpha 1$ cell proliferation or tumor growth in vivo, which supports our recent report that adrenocortical tumor progression in inh $\alpha /$ Tag mice may be gonadotropin independent (Doroszko et al. 2017b). Additionally, the systemic action of CTX treatment in vivo was manifested by reduced plasma concentrations of $\mathrm{LH}$ and progesterone levels. Combining hCG with CTX treatment did not affect the outcome, implying that the CTX effect was independent of gonadotropin suppression but rather a direct effect on the adrenal tumors. Previously, H295R cells have been shown to express LHCGR and respond to hCG stimulation by producing DHEAS (Rao et al. 2004). In the current study, we confirmed the LHCGR expression in H295R adrenocortical carcinoma cells and showed that hCG stimulation resulted in mitotic effect. These data suggest a scenario of combined CTX action by direct blockage of adrenocortical tumor progression and indirect suppression of LH and steroid hormone concentrations that could be used for the benefit of the patient.
Gonadectomized domestic ferrets are another model that develops malignant adrenocortical tumors with gonadal-like phenotype (Li et al. 1998). Similar to inh $\alpha /$ Tag mice, tumor onset in ferrets was attributed to LH action. Therefore, therapies with GnRH agonist (Wagner et al. 2001, 2005) or GnRH adjuvant (Miller et al. 2013) to block circulating gonadotropins and subsequent hormone excess have been effective. It would be interesting to validate the LH dependency of the tumor progression and the expression of GNRHR in the ferret adrenal tumor tissues, as they could serve as another model for adrenocortical carcinomas.

Although the anti-angiogenic, anti-metastatic and pro-apoptotic effects of GnRH antagonists are well documented (Ghanghoria et al. 2016), the molecular mechanisms of their action remains poorly understood. A study on prostate cancer cell lines, with a different GnRH antagonist, degarelix, showed rather discrete mRNA changes after in vitro treatment (Sakai et al. 2015). It was suggested that the initial effects of GnRH antagonist could be non-genomic, directly triggering apoptosis in the effector cells (Sakai et al. 2015). To investigate the molecular changes in tumor cells induced by CTX, we carried out microarray analyses supported by qPCR validation. Arrays of genes were found upregulated, such as (Mmp24, Rerg, Grb10, Gnrhr, Gnas, Nfatc2 and Sgcd) and downregulated, such as (Gata4 and Lhcgr), in agreement with a previous study where tumorous and WT adrenals were compared (Doroszko et al. 2017a). Moreover, we have identified downregulation of Ccna1, an important contributor to G1/S cell cycle transition in somatic cells (Ji et al. 2005) and upregulation of genes related to cell growth suppression, such as G0s2 (Welch et al. 2009) and Tusc5 (Konishi et al. 2003), Rasgrf2 (Qiu et al. 2003) in the CTX vs CT-treated adrenals. Interestingly, none of the investigated genes was affected in the C $\alpha 1$ and Y-1 cell lines treated with CTX. This suggests that the regulation of gene expression does not proceed in the same fashion when tumor cells are grown in vitro. Downregulation of the tumor biomarkers Gata4 and Lhcgr could be a sign of regressing tumor cells. On the other hand, the upregulated Grb10, Rerg, Gnas and Nfatc2, recently localized in abundance in the healthy adrenal gland (Doroszko et al. 2017a), could be a sign of physiological and regenerative response to replenish healthy adrenal. Therefore, our findings support the idea that the GnRH antagonist functions as a safe antitumor treatment that selectively and directly kills adrenocortical tumor cells.

Taken together, our data suggest that the GnRH antagonist cetrorelix acetate acts directly on adrenocortical

This work is licensed under a Creative Commons Attribution 4.0 International License. 
tumor cells causing their apoptosis. The compound could improve the therapy of both hormone-secreting and non-secreting adrenocortical carcinomas both through systemic and direct action.

\section{Supplementary data}

This is linked to the online version of the paper at https://doi.org/10.1530/ ERC-17-0399.

\section{Declaration of interest}

The authors declare that there is no conflict of interest that could be perceived as prejudicing the impartiality of the research reported.

\section{Funding}

The authors would like to thank Erica Nyman and Marja-Riitta Kajaala from the Turku Center for Disease Modeling (TCDM) for technical assistance. This work was financially supported by Turku Doctoral Programme of Molecular Medicine (M D), Finnish Cultural Foundation (M D), Academy of Finland ( $N A R, J T)$, Sigrid Juselius Foundation (J T), ERVA grant from Turku University Hospital (J T) and Polish National Science Center grant 2015/17/B/N25/00636 (N A R).

\section{Author contribution statement}

M D, M C, N A R designed the study concept; M D, M C, J S, TS, S A performed the experiments; all the authors (M D, M C, J S, T S, S A, U P, M Q, S W, I $H, J T, N A R$ ) analyzed and interpreted the results; $M D, M C, I H, J$ T and $\mathrm{N}$ A R drafted the manuscript and all the authors have approved the final manuscript.

\section{References}

Albiger N, Sartorato P, Mariniello B, Iacobone M, Finco I, Fassina A \& Mantero F 2011 A case of primary aldosteronism in pregnancy: do $\mathrm{LH}$ and GNRH receptors have a potential role in regulating aldosterone secretion? European Journal of Endocrinology of the European Federation of Endocrine Societies 164 405-412. (https://doi.org/10.1530/EJE-10-0879)

Alevizaki M, Saltiki K, Mantzou E, Anastasiou E \& Huhtaniemi I 2006 The adrenal gland may be a target of LH action in postmenopausal women. European Journal of Endocrinology of the European Federation of Endocrine Societies 154 875-881. (https://doi.org/10.1530/eje.1.02165)

Allolio B \& Fassnacht M 2006 Clinical review: adrenocortical carcinoma: clinical update. Journal of Clinical Endocrinology and Metabolism 91 2027-2037. (https://doi.org/10.1210/jc.2005-2639)

Banerjee P \& Fazleabas AT 2011 Extragonadal actions of chorionic gonadotropin. Reviews in Endocrine and Metabolic Disorders 12 323-332. (https://doi.org/10.1007/s11154-011-9193-1)

Bernichtein S, Alevizaki M \& Huhtaniemi IT 2008 Is the adrenal cortex a target for gonadotropins? Trends in Endocrinology and Metabolism 19 231-238. (https://doi.org/10.1016/j.tem.2008.06.003)

Bodek G, Vierre S, Rivero-Müller A, Huhtaniemi I, Ziecik AJ \& Rahman NA 2005 A novel targeted therapy of leydig and granulosa cell tumors through the luteinizing hormone receptor using a Hecatechorionic gonadotropin $\beta$ conjugate in transgenic mice. Neoplasia 7 497-508. (https://doi.org/10.1593/neo.04751)
Bonomi M, Busnelli M, Persani L, Vassart G \& Costagliola S 2006 Structural differences in the hinge region of the glycoprotein hormone receptors: evidence from the sulfated tyrosine residues. Molecular Endocrinology 20 3351-3363. (https://doi.org/10.1210/ me.2005-0521)

Carlson HE 2007 Human adrenal cortex hyperfunction due to LH/hCG. Molecular and Cellular Endocrinology 269 46-50. (https://doi. org/10.1016/j.mce.2006.06.014)

Chrusciel M, Doroszko M, Stelmaszewska J, Li X, Ziecik AJ, CoelinghBennink HJ, Huhtaniemi I \& Rahman NA 2014 Transgenic mice expressing inhibin alpha-subunit promoter (inhalpha)/Simian Virus 40 T-antigen (Tag) transgene as a model for the therapy of granulosa cell-derived ovarian cancer. Reproductive Biology 14 25-31. (https:// doi.org/10.1016/j.repbio.2013.11.005)

Cohen AI, Bloch E \& Celozzi E 1957 In vitro response of functional experimental adrenal tumors to corticotropin (ACTH). Proceedings of the Society for Experimental Biology and Medicine 95 304-309. (https://doi.org/10.3181/00379727-95-23202)

Creemers SG, Hofland L, Korpershoek E, Franssen G, van Kemenade FJ, de Herder WW \& Feelders R 2016 Future directions in the diagnosis and medical treatment of adrenocortical carcinoma. Endocrine-Related Cancer 23 R43-R69. (https://doi.org/10.1530/ERC-15-0452)

Doroszko M, Chrusciel M, Belling K, Vuorenoja S, Dalgaard M, Leffers H, Nielsen HB, Huhtaniemi I, Toppari J \& Rahman NA $2017 a$ Novel genes involved in pathophysiology of gonadotropindependent adrenal tumors in mice. Molecular and Cellular Endocrinology 444 9-18. (https://doi.org/10.1016/j. mce.2017.01.036)

Doroszko M, Chrusciel M, Stelmaszewska J, Slezak T, Rivero-Muller A, Padzik A, Anisimowicz S, Wolczynski S, Huhtaniemi I, Toppari J, et al. 2017b Luteinizing hormone and GATA4 action in the adrenocortical tumorigenesis of gonadectomized female mice. Cellular Physiology and Biochemistry 43 1064-1076. (https://doi. org/10.1159/000481718)

Fassnacht M \& Allolio B 2009 Clinical management of adrenocortical carcinoma. Best Practice and Research 23 273-289. (https://doi. org/10.1016/j.beem.2008.10.008)

Ghanghoria R, Kesharwani P, Tekade RK \& Jain NK 2016 Targeting luteinizing hormone-releasing hormone: a potential therapeutics to treat gynecological and other cancers. Journal of Controlled Release. (https://doi.org/10.1016/j.jconrel.2016.11.002)

Hellemans J, Mortier G, De Paepe A, Speleman F \& Vandesompele J 2007 qBase relative quantification framework and software for management and automated analysis of real-time quantitative PCR data. Genome Biology 8 R19. (https://doi.org/10.1186/gb-2007-82-r19)

Huhtaniemi I 2010 Are gonadotrophins tumorigenic-a critical review of clinical and experimental data. Molecular and Cellular Endocrinology 329 56-61. (https://doi.org/10.1016/j.mce.2010.04.028)

Jääskeläinen M, Nieminen A, Pökkylä R-M, Kauppinen M, Liakka A, Heikinheimo M, Vaskivuo TE, Klefström J \& Tapanainen JS 2010 Regulation of cell death in human fetal and adult ovaries-role of Bok and Bcl-X L. Molecular and Cellular Endocrinology 330 17-24. (https://doi.org/10.1016/j.mce.2010.07.020)

Ji P, Agrawal S, Diederichs S, Bäumer N, Becker A, Cauvet T, Kowski S, Beger C, Welte K, Berdel WE, et al. 2005 Cyclin A1, the alternative A-type cyclin, contributes to G1/S cell cycle progression in somatic cells. Oncogene $\mathbf{2 4}$ 2739-2744. (https://doi.org/10.1038/sj.onc.1208356)

Kananen K, Markkula M, Rainio E, Su JG, Hsueh AJ \& Huhtaniemi IT 1995 Gonadal tumorigenesis in transgenic mice bearing the mouse inhibin alpha-subunit promoter/simian virus T-antigen fusion gene: characterization of ovarian tumors and establishment of gonadotropin-responsive granulosa cell lines. Molecular Endocrinology 9 616-627. (https://doi.org/10.1210/mend. 9.5.7565808) 
Kananen K, Markkula M, Mikola M, Rainio EM, McNeilly A \& Huhtaniemi I 1996 Gonadectomy permits adrenocortical tumorigenesis in mice transgenic for the mouse inhibin alphasubunit promoter/simian virus 40 T-antigen fusion gene: evidence for negative autoregulation of the inhibin alpha-subunit gene. Molecular Endocrinology 10 1667-1677. (https://doi.org/10.1210/ mend.10.12.8961275)

Konishi H, Sugiyama M, Mizuno K, Saito H, Yatabe Y, Takahashi T, Osada H \& Takahashi T 2003 Detailed characterization of a homozygously deleted region corresponding to a candidate tumor suppressor locus at distal 17p13. 3 In human lung cancer. Oncogene 22 1892-1905. (https://doi.org/10.1038/sj.onc.1206304)

Lacroix A, Bourdeau I, Lampron A, Mazzuco TL, Tremblay J \& Hamet P 2010 Aberrant G-protein coupled receptor expression in relation to adrenocortical overfunction. Clinical Endocrinology 73 1-15. (https:// doi.org/10.1111/j.1365-2265.2009.03689.x)

Li X, Fox J \& Padrid P 1998 Neoplastic diseases in ferrets: 574 cases (1968-1997). Journal of the American Veterinary Medical Association 212 1402-1406.

Limonta P, Marelli MM, Mai S, Motta M, Martini L \& Moretti RM 2012 GnRH receptors in cancer: from cell biology to novel targeted therapeutic strategies. Endocrine Reviews 33 784-811. (https://doi. org/10.1210/er.2012-1014)

Mi H, Muruganujan A, Casagrande JT \& Thomas PD 2013 Large-scale gene function analysis with the PANTHER classification system. Nature Protocols 8 1551-1566. (https://doi.org/10.1038/ nprot.2013.092)

Mikola M, Kero J, Nilson JH, Keri RA, Poutanen M \& Huhtaniemi I 2003 High levels of luteinizing hormone analog stimulate gonadal and adrenal tumorigenesis in mice transgenic for the mouse inhibin- $\alpha$ subunit promoter/Simian virus 40 T-antigen fusion gene. Oncogene 22 3269-3278. (https://doi.org/10.1038/sj.onc.1206518)

Miller LA, Fagerstone KA, Wagner RA \& Finkler M 2013 Use of a GnRH vaccine, GonaCon ${ }^{\mathrm{TM}}$, for prevention and treatment of adrenocortical disease (ACD) in domestic ferrets. Vaccine 31 4619-4623. (https:// doi.org/10.1016/j.vaccine.2013.07.035)

Pabon JE, Li X, Lei ZM, Sanfilippo JS, Yussman MA \& Rao CV 1996 Novel presence of luteinizing hormone/chorionic gonadotropin receptors in human adrenal glands. Journal of Clinical Endocrinology and Metabolism 81 2397-2400. (https://doi.org/10.1210/ jcem.81.6.8964884)

Park MK, Kanaho Y-I \& Enomoto M 2013 Regulation of the cell proliferation and migration as extra-pituitary functions of GnRH. General and Comparative Endocrinology 181 259-264. (https://doi. org/10.1016/j.ygcen.2012.09.023)

Pawlikowski M, Pisarek H, Kubiak R, Jaranowska M \& Stępień H 2012 Immunohistochemical detection of FSH receptors in pituitary adenomas and adrenal tumors. Folia Histochemica et Cytobiologica $\mathbf{5 0}$ 325-330. (https://doi.org/10.5603/17850)

Plöckinger U, Chrusciel M, Doroszko M, Saeger W, Blankenstein O, Weizsäcker K, Kroiss M, Hauptmann K, Radke C, Pöllinger A, et al. 2017 Functional implications of LH/hCG receptors in pregnancyinduced Cushing syndrome. Journal of the Endocrine Society 1 57-71. (https://doi.org/10.1210/js.2016-1021)

Qiu C, Yu M, Liang S \& Snyderwine EG 2003 Allelic imbalance and altered expression of genes in chromosome $2 \mathrm{q} 11-2 \mathrm{q} 16$ from rat mammary gland carcinomas induced by 2-amino-1-methyl-6phenylimidazo [4, 5-b] pyridine. Oncogene 22 1253-1260. (https:// doi.org/10.1038/sj.onc.1206233)

Rahman NA, Kiiveri S, Siltanen S, Levallet J, Kero J, Lensu T, Wilson DB, Heikinheimo MT \& Huhtaniemi IT 2001 Adrenocortical tumorigenesis in transgenic mice: the role of luteinizing hormone receptor and transcription factors GATA-4 and GATA-61. Reproductive Biology 1 5-9.

Rahman NA, Kiiveri S, Rivero-Muller A, Levallet J, Vierre S, Kero J, Wilson DB, Heikinheimo M \& Huhtaniemi I 2004 Adrenocortical tumorigenesis in transgenic mice expressing the inhibin alphasubunit promoter/simian virus $40 \mathrm{~T}$-antigen transgene: relationship between ectopic expression of luteinizing hormone receptor and transcription factor GATA-4. Molecular Endocrinology 18 2553-2569. (https://doi.org/10.1210/me.2002-0282)

Rainey WE, Bird IM \& Mason JI 1994 The NCI-H295 cell line: a pluripotent model for human adrenocortical studies. Molecular and Cellular Endocrinology 100 45-50. (https://doi.org/10.1016/03037207(94)90277-1)

Rao CV, Zhou X \& Lei Z 2004 Functional luteinizing hormone/chorionic gonadotropin receptors in human adrenal cortical H295R cells. Biology of Reproduction 71 579-587. (https://doi.org/10.1095/ biolreprod.104.027300)

Rilianawati PT, Kero J, Zhang FP, Rahman N, Kananen K, Huhtaniemi I \& Huhtaniemi I 1998 Direct luteinizing hormone action triggers adrenocortical tumorigenesis in castrated mice transgenic for the murine inhibin alpha-subunit promoter/simian virus 40 T-antigen fusion gene. Molecular Endocrinology 12 801-809. (https://doi. org/10.1210/mend.12.6.0117)

Rilianawati RNA, Huhtaniemi I \& Huhtaniemi I 1999 Hormonal regulation of proliferation of granulosa and Leydig cell lines derived from gonadal tumors of transgenic mice expressing the inhibinalpha subunit promoter/simian virus 40 T-antigen fusion gene. Molecular and Cellular Endocrinology 149 9-17. (https://doi. org/10.1016/S0303-7207(99)00004-0)

Risma KA, Clay CM, Nett TM, Wagner T, Yun J \& Nilson JH 1995 Targeted overexpression of luteinizing hormone in transgenic mice leads to infertility, polycystic ovaries, and ovarian tumors. PNAS 92 1322-1326. (https://doi.org/10.1073/pnas.92.5.1322)

Sakai M, Martinez-Arguelles DB, Patterson NH, Chaurand P \& Papadopoulos V 2015 In search of the molecular mechanisms mediating the inhibitory effect of the GnRH antagonist degarelix on human prostate cell growth. PLOS ONE 10 e0120670. (https://doi. org/10.1371/journal.pone.0120670)

Seitz S, Buchholz S, Schally AV, Weber F, Klinkhammer-Schalke M, Inwald EC, Perez R, Rick FG, Szalontay L, Hohla F, et al. 2014 Triple negative breast cancers express receptors for LHRH and are potential therapeutic targets for cytotoxic LHRH-analogs, AEZS 108 and AEZS 125. BMC Cancer 14 847. (https://doi.org/10.1186/1471-2407-14-847)

Stelmaszewska J, Chrusciel M, Doroszko M, Akerfelt M, PonikwickaTyszko D, Nees M, Frentsch M, Li X, Kero J, Huhtaniemi I, et al. 2016 Revisiting the expression and function of follicle-stimulation hormone receptor in human umbilical vein endothelial cells. Scientific Reports 6 37095. (https://doi.org/10.1038/srep37095)

Thompson GB \& Young Jr WF 2003 Adrenal incidentaloma. Current Opinion in Oncology 15 84-90. (https://doi.org/10.1097/00001622200301000-00013)

Tuominen VJ, Ruotoistenmäki S, Viitanen A, Jumppanen M \& Isola J 2010 ImmunoRatio: a publicly available web application for quantitative image analysis of estrogen receptor (ER), progesterone receptor (PR), and Ki-67. Breast Cancer Research 12 R56. (https://doi. org/10.1186/bcr2615)

Vannier B, Loosfelt H, Meduri G, Pichon C \& Milgrom E 1996 Antihuman FSH receptor monoclonal antibodies: immunochemical and immunocytochemical characterization of the receptor. Biochemistry 35 1358-1366. (https://doi.org/10.1021/bi952290f)

Vuorenoja S, Rivero-Muller A, Kiiveri S, Bielinska M, Heikinheimo M, Wilson DB, Huhtaniemi IT \& Rahman NA 2007 Adrenocortical tumorigenesis, luteinizing hormone receptor and transcription factors GATA-4 and GATA-6. Molecular and Cellular Endocrinology 269 38-45. (https://doi.org/10.1016/j.mce.2006.11.013)

Vuorenoja S, Rivero-Muller A, Ziecik AJ, Huhtaniemi I, Toppari J \& Rahman NA 2008 Targeted therapy for adrenocortical tumors in transgenic mice through their LH receptor by Hecate-human chorionic gonadotropin beta conjugate. Endocrine-Related Cancer 15 635-648. (https://doi.org/10.1677/ERC-08-0015) 
Vuorenoja S, Mohanty BP, Arola J, Huhtaniemi I, Toppari J \& Rahman NA 2009 Hecate-CGbeta conjugate and gonadotropin suppression shows two distinct mechanisms of action in the treatment of adrenocortical tumors in transgenic mice expressing Simian Virus $40 \mathrm{~T}$ antigen under inhibin-alpha promoter. Endocrine-Related Cancer 16 549-564. (https://doi.org/10.1677/ERC-08-0232)

Wagner RA, Bailey EM, Schneider JF \& Oliver JW 2001 Leuprolide acetate treatment of adrenocortical disease in ferrets. Journal of the American Veterinary Medical Association 218 1272-1274. (https://doi. org/10.2460/javma.2001.218.1272)

Wagner RA, Piché CA, Jöchle W \& Oliver JW 2005 Clinical and endocrine responses to treatment with deslorelin acetate implants in ferrets with adrenocortical disease. American Journal of Veterinary Research 66 910-914. (https://doi.org/10.2460/ajvr.2005.66.910)
Wang F, Flanagan J, Su N, Wang LC, Bui S, Nielson A, Wu X, Vo HT, Ma XJ \& Luo Y 2012 RNAscope: a novel in situ RNA analysis platform for formalin-fixed, paraffin-embedded tissues. Journal of Molecular Diagnostics 14 22-29. (https://doi.org/10.1016/j.jmoldx.2011.08.002) Welch C, Santra MK, El-Assaad W, Zhu X, Huber WE, Keys RA, Teodoro JG \& Green MR 2009 Identification of a protein, G0S2, that lacks Bcl-2 homology domains and interacts with and antagonizes Bcl-2. Cancer Research 69 6782-6789. (https://doi.org/10.1158/0008-5472.CAN-09-0128)

Ziegler C, Brown J, Schally AV, Erler A, Gebauer L, Treszl A, Young L, Fishman L, Engel J, Willenberg H, et al. 2009 Expression of neuropeptide hormone receptors in human adrenal tumors and cell lines: antiproliferative effects of peptide analogues. PNAS 106 15879-15884. (https://doi.org/10.1073/pnas.0907843106)

Received in final form 13 August 2018

Accepted 21 August 2018
This work is licensed under a Creative Commons Attribution 4.0 International License. 